\title{
Prey preference and life tables of the predatory mite Parasitus bituberosus (Acari: Parasitidae) when offered various prey combinations
}

\author{
Piotr Szafranek • Mariusz Lewandowski • Marcin Kozak
}

Received: 8 February 2010/Accepted: 19 April 2013/Published online: 3 May 2013

(C) The Author(s) 2013. This article is published with open access at Springerlink.com

\begin{abstract}
Parasitus bituberosus Karg (Acari: Parasitidae) is one of the predatory mite species inhabiting mushroom houses. It is known to accept a wide range of prey, suggesting that it may be a promising candidate for the biological control of key pests of mushroom culture. In our study it did not show any prey preference among four groups of small organisms often occurring in mushroom growth medium, namely rhabditid nematodes, pygmephorid mites, and sciarid and phorid fly larvae. Nevertheless, the type of food these predators fed on affects their development. The shortest egg-to-adult development time was obtained on a nematode diet. On a diet of phorid larvae, mite development stopped at the deutonymph stage; none reached adulthood. All other diets sufficed to reach the adult phase. Female fecundity when fed nematodes and sciarid larvae did not differ, but it was much lower when fed pygmephorid mites. Other life table parameters confirmed that pygmephorid mites constituted the worst diet for $P$. bituberosus. The highest intrinsic rate of population increase $\left(r_{m}=0.34\right)$ was obtained on the nematode diet; when fed sciarid larvae and pygmephorid mites it was 0.25 and 0.14 , respectively. Our study provides good reasons to further test $P$. bituberosus as biocontrol agent of especially sciarid flies and nematodes, especially when the compost is well colonized by mushroom mycelium (which retards nematode growth).
\end{abstract}

Keywords Mushroom pest · Biological control · Prey choice test · Population parameters

P. Szafranek $\cdot$ M. Lewandowski $(\bowtie)$

Department of Applied Entomology, Faculty of Horticulture, Biotechnology and Landscape

Architecture, Warsaw University of Life Sciences-SGGW, Nowoursynowska 159, 02-776 Warsaw,

Poland

e-mail: mariusz_lewandowski@sggw.pl

Present Address:

P. Szafranek

Research Institute of Horticulture, Konstytucji 3 Maja 1/3, 96-100 Skierniewice, Poland

M. Kozak

Department of Botany, Faculty of Agriculture and Biology, Warsaw University

of Life Sciences-SGGW, Nowoursynowska 159, 02-776 Warsaw, Poland 


\section{Introduction}

The mushroom environment with its large amount of decaying organic material, mycelium and sporophores is favourable for many small animals. Some of them can feed on the mushrooms and can be treated as pests. Others, mainly predatory mites, can feed on these pests, limiting their populations. Studies conducted in mushroom houses in Poland in the 1980s showed the occurrence of 19 mite species belonging to eight families. Among them 11 predatory species, from four families: Macrochelidae, Eviphididae, Ascidae and Rhodacaridae (Kropczyńska-Linkiewicz 1984). Twenty years later, also the parasitid Rhabdocarpais consanguineus (Oudemans and Voigts) (syn. Parasitus consanguineus Oudemans and Voigts) was found in a few Polish mushroom houses (Szlendak and Lewandowski 2000). This species was first found in mushroom houses by Gill et al. (1988) and Trivedi (1988). Another species of the Parasitidae family, Parasitus bituberosus Karg, was noted in cultivated mushroom beds by Binns (1973a) and Al-Amidi and Downes (1990).

A few insect species were listed as the main pests of mushroom culture, causing direct and indirect damage by feeding on mycelium and mushroom sporophores, contaminating the crop and transmitting spores of mushroom diseases (Hussey et al. 1969; White 1981, 1986; Rinker and Snetsinger 1984). Among the mites occurring in mushroom houses, species from the Acaridae, Tarsonemidae, Siteroptidae and Histiostomatidae were mentioned as economically important (Hussey et al. 1969). The most common is Pediculaster mesembrinae (Canestrini), which can thrive while feeding on weed moulds, but it is unable to feed and reproduce on substrate colonized by mushroom mycelium. However, the mites can indirectly injure mushroom culture by favoring the development of the parasitic fungi Trichoderma harzianum and T. viride. Simultaneous infestation of P. mesembrinae and Histiostoma feroniarum (Dufour) resulted in 20-40\% reduction in mushroom yield (Clift and Terras 1995). In a group of nematodes infesting mushroom houses, the most destructive species can feed on mushroom mycelium, causing significant reductions in yield. Symptoms that can be noticed after their feeding are bare patches or sunken areas of bed. Fortunately, these species are not as common in the mushroom environment as bacterivorous rhabditid nematodes. In Polish mushroom houses, $90 \%$ of all nematodes found in casing were represented by Rhabditis cucumeris Marcinowski. Presence of the mites in the compost delayed development of mushroom mycelium (Dmowska et al. 1997).

Chemical control of dipteran pests associated with the cultivation of mushrooms is unsatisfactory, which has led to an increasing interest in biological control (Al-Amidi and Downes 1990). Usage of predatory mites for mushroom pest control was initiated by Binns (1972, 1973b, 1974), who studied mites phoretic on mushroom flies. He found that Digamasellus fallax (Leitner), phoretic on sciarid flies, accepts nematodes as food. Equally common Arctoseius cetratus (Sellnick), also phoretic on flies, can attack sciarid larvae and eggs, cecid larvae, tarsonemid mites and rhabditid nematodes. Another Arctoseius species, A. semiscissus (Berlese), was recorded on reared mushrooms in Poland by Dmoch (1995), who considered this phoretic mite a potential agent for sciarid fly control. Soil-dwelling mites are another group studied for their potential use in biological control. Hypoaspis miles (Berlese) and $H$. aculeifer (Canestrini) were proven effective against sciarids of the genus Bradysia (Gillespie and Quiring 1990; Chambers et al. 1993; Wright and Chambers 1994), Lycoriella ingenua (Dufour) (Enkegaard et al. 1997; Jess and Bingham 2004) and the phorid Megaselia halterata (Wood) (Jess and Bingham 2004).

Mushroom substrate based on peat, manure and straw may constitute a perfect environment for P. bituberosus (Hyatt 1980). In mushroom beds it can find much of various 
kinds of food, such as nematodes, saprophagous and mycophagous mites, springtails, and dipteran larvae of the families Sciaridae, Phoridae and Cecidomyiidae (Hussey et al. 1969; Al-Amidi and Downes 1990; Al-Amidi et al. 1991). Used as a biological control agent of dipteran larvae, P. bituberosus prevented the cecidomyiid Heteropeza pygmaea Winertz from building up high populations. It was also able to limit populations of the sciarid $L$. ingenua by 50-66 \%. Larvae of L. ingenua and M. halterata were also accepted as a prey by $R$. consanguineus. Studies showed that $R$. consanguineus can complete development on a diet of larvae of $M$. halterata and L. ingenua, which indicates that it has potential as a predatory mite for controlling both these pest species (Szlendak and Lewandowski 2009). The studies mentioned suggest that predatory mites in mushroom houses can be considered as natural enemies of mushroom pests, and that some of them may replace chemicals in mushroom pest control.

According to Al-Amidi and Downes (1990) and Al-Amidi et al. (1991), one of the most interesting species seems to be $P$. bituberosus. To date little is known about its biology and influence on mushroom yield. Al-Amidi et al. (1991) found that sciarid fly control by these mites led to an $18 \%$ increase in mushroom yield. Considering the relatively large size of the mites, it will also be interesting to study its influence on transmitting spores of mushroom diseases and mushroom crop quality. Here, as a first step of ongoing investigations, we study the influence of prey types on the biology of $P$. bituberosus. Specifically, we study (a) prey preferences of $P$. bituberosus feeding on some small animals commonly occurring as pests in mushroom houses, viz. rhabditid nematodes, pygmephorid mites and dipteran larvae, and (b) the influence of the food on development of the mites. Such knowledge will constitute a basis for further research on the role of P. bituberosus in mushroom production.

\section{Materials and methods}

Specimens of $P$. bituberosus for our experiments were obtained from a stock colony that had been established with mites collected in 2005 from two commercial mushroom houses located near Warsaw, Poland. Colonies were maintained in the laboratory at $25^{\circ} \mathrm{C}$ in six plastic boxes filled to $1 / 3$ height with horse dung. Rhabditid nematodes were added to the boxes as prey. For keeping colonies in good condition, every 2 weeks two new boxes were prepared and the two oldest were removed.

Four types of diets were used to study prey preferences of P. bituberosus: (1) bacterivorous nematodes of Rhabditis sp., (2) 2nd instar larvae of the sciarid fly L. ingenua (3) 2nd instar larvae of the phorid fly $M$. halterata, and (4) all developmental stages of the fungivorous mite $P$. mesembrinae. Prey preferences of starving females and deutonymphs were studied in choice tests conducted in a plastic arena. The prey were placed separately in small plastic cups ( $8 \mathrm{~mm}$ diameter and $5 \mathrm{~mm}$ high). To one cup, a small amount of compost inoculated with mushroom mycelium was added along with one larva of sciarid or phorid fly, 10 females of pygmephorid mites, or about 300 individuals of rhabditid nematodes. Higher numbers of pygmephorid mites and nematodes were added than fly larvae, to roughly equalize the amount of biomass of available prey. Plastic Petri dishes $(10 \mathrm{~cm}$ diameter) were used as an arena. At the bottom of the Petri dish, wet blotting paper was laid to prevent the mites to desiccate. 4 cups, containing different diets, were placed symmetrically inside Petri dishes, and one individual of P. bituberosus starving for $24 \mathrm{~h}$ was placed in the centre of the dish. A new arena was constructed for each predator specimen examined. The kind of prey chosen, time of searching the prey and time of 
feeding were scored. The predatory mites were observed until they ended feeding; if a specimen did not choose any cup within an hour or if any prey left the cup (thereby confounding the set-up), it was rejected. When a predator specimen entered a cup and started feeding, this was treated as choosing the food and as the end of searching time; leaving the cup after eating one or more specimens of prey was treated as the end of feeding. If they visited a cup and left it without feeding, searching time was measured until the moment of feeding on some other prey. The tests were conducted for 30 females and 42 deutonymphs, used only once in the test.

\section{Life table parameters}

The experiments were conducted in glass rearing cages $(4.0 \times 3.5 \times 0.5 \mathrm{~cm})$ with a centrally drilled conical hole of 7-15 mm diameter. Filter paper was attached on one side of the cage, using hot wax as an adhesive. The other side of the cage was covered with a microscope slide cover slip attached to the glass by strips of sticky label tape.

One pair of $P$. bituberosus was placed in each cage, with a small amount of horse dung and nematodes as a diet. After $24 \mathrm{~h}$, eggs of P. bituberosus were selected under a stereomicroscope, and put separately in rearing cages filled with one of the four diets, used in prey preferences tests: (1) rhabditid nematodes, (2) 1st or 2nd instar sciarid larvae, (3) 1st or 2 nd instar phorid larvae, or (4) all developmental stages of pygmephorid mites. The amount of prey supplied was in excess of what the predators eat maximally. The rearing cages were placed in controlled-temperature cabinets maintained at $25( \pm 0.5){ }^{\circ} \mathrm{C}$ and $12 \mathrm{~h}$ daily photophase.

Fifty eggs of $P$. bituberosus were used for each food type. Fresh food was given to the rearing cages every day. After reaching the deutonymph stage, mites were moved separately to plastic boxes of about $130 \mathrm{ml}$ capacity, filled with about $10 \mathrm{ml}$ of horse dung and the corresponding diet, to moult into adults. The viability of eggs, larvae, proto- and deutonymphs as well as the duration of their development was established by daily recording the number of live and dead individuals. Mortality, longevity and fecundity of females were also recorded by placing one-day-old pairs of P. bituberosus in separate, small rearing cages, replaced daily by new ones, containing fresh food. Because multiple mating increases egg production (Yasui 1997), a male was replaced if it died earlier than the female. To obtain more data on female development parameters, an additional series of experiments was established with an additional group of $P$. bituberosus, reared under the same conditions and on the same type of diet as in the main experiment.

\section{Statistical analysis}

Results of choice tests were analyzed through the $\chi^{2}$ test for analyzing frequencies (Agresti 2002). Time of searching the prey and time of feeding were analyzed through analysis of variance; in case of lack of fit of the analysis of variance model, as suggested by graphical diagnostics methods, generalized least square estimation was employed with a best-fit variance function (Pinheiro and Bates 2000), with the help of 'nlme' package of R. For significant models, Tukey's contrasts without adjustment for multiple testing were employed. Survival rate of $P$. bituberosus on different diets for subsequent stages was analyzed through generalized linear models with a binomial error distribution (Agresti 2002). Tukey's contrasts for generalized linear models (Hothorn et al. 2008) were employed to compare the diets in terms of survival rate on different diets (the diets for which $l_{x}=0$ were removed from the multiple comparisons); no adjustment was made for 
multiple testing (Webster 2007; Kozak 2009). The significance level for all the analyses was 0.05. The analysis was conducted in R (R Development Core Team 2009); for multiple comparisons, the package 'multcomp' (Hothorn et al. 2008) was employed. Differences of the stages among diets in mean development time, longevity of females, number of eggs laid, and duration of oviposition period were studied in the same way as time of searching the prey and time of feeding, as described above.

Life tables were constructed from the observed age-specific survival rate $\left(l_{x}\right)$ and agespecific fecundity rate $\left(m_{x}\right)\left[R_{O}\right.$, net reproductive rate (female progeny per female); $T$, mean generation time (days); $r_{m}$, intrinsic rate of population increase (female per female per day); $\lambda$, finite rate of population increase (female per female per day)] (Birch 1948). For estimation of standard errors and multiple comparison of the diets in terms of these life table parameters, the jackknife method was employed (Maia et al. 2000), without adjustment for multiple testing.

Age-specific survival rate of $P$. bituberosus females on different food diets was analyzed as a Weibull function of day (Pinder et al. 1978), fitted by means of a nonlinear least squares method, using $\mathrm{R}$.

\section{Results}

Prey preferences

Frequency analysis did not show any differences in choice of particular food diets of females $\left(\chi^{2}=0.667 ; d f=3 ; P=0.84\right)$ and deutonymphs $\left(\chi^{2}=0.857 ; d f=3 ; P=0.88\right)$ of the predatory mite $P$. bituberosus.

Time of searching the prey was determined only by developmental stage $(P<0.001)$; the effects of prey and interaction were not significant $(P=0.46$ and 0.94 , respectively). Females reached the prey much faster (with the mean of $6.0 \mathrm{~min}$ ) than deutonymphs (17.3 min).

Time of feeding was determined only by prey $(P=0.004)$; the effect of neither developmental stage $(P=0.71)$ nor interaction $(P=0.42)$ was significant. The mean time of feeding was the shortest for nematodes, and the longest for phorid and sciarid larvae (Table 1).

\section{Life table parameters}

Predatory mites $P$. bituberosus were able to complete their life cycle on all the food diets except phorid fly larvae, for which no adult individuals were obtained during the experiments. The age-specific survival rate of immatures differed among diets $(P=0.017)$, but no significant differences were observed at the beginning of the deutonymph stage class. The worst diet was phorid larvae, for which the parameter reached zero at the beginning of the adult age class (Table 2).

Development time of preimaginal stages (from egg to adult) of P. bituberosus significantly differed among diets $(P \leq 0.001)$; nematodes constituted the best food, on which immature stages of the mites developed faster than on the other diets (Table 3).

Diets did not affect $P$. bituberosus female longevity $(P=0.19)$, but affected total fecundity $(P<0.001)$. The lowest fecundity was observed for females fed upon pygmephorid mites, whereas no difference was detected between fecundity of females fed upon rhabditid nematodes and sciarid larvae. The same situation was observed for daily 
Table 1 Mean $( \pm \mathrm{SD})$ time of searching the prey and time of feeding for two stages of Parasitus bituberosus on different food sources

\begin{tabular}{|c|c|c|c|c|c|c|c|c|}
\hline \multirow[t]{2}{*}{ Prey } & \multicolumn{4}{|c|}{ Searching time } & \multicolumn{4}{|c|}{ Feeding time } \\
\hline & $\mathrm{n}$ & Female & $\mathrm{n}$ & Deutonymph & $\mathrm{n}$ & Female & $\mathrm{n}$ & Deutonymph \\
\hline Rhabditid nematodes & 9 & $4.1 \pm 1.3 \mathrm{aA}$ & 12 & $18.2 \pm 17.5 \mathrm{aB}$ & 9 & $13.4 \pm 1.3 \mathrm{aA}$ & 12 & $9.2 \pm 5.2 \mathrm{aA}$ \\
\hline Pygmephorid mites & 6 & $4.7 \pm 4.5 \mathrm{aA}$ & 9 & $12.2 \pm 7.7 \mathrm{aB}$ & 6 & $15.5 \pm 7.6 \mathrm{abA}$ & 9 & $15.3 \pm 10.0 \mathrm{abA}$ \\
\hline Sciarid larvae & 8 & $6.6 \pm 6.6 \mathrm{aA}$ & 12 & $20.3 \pm 14.6 \mathrm{aB}$ & 8 & $19.0 \pm 11.1 \mathrm{bA}$ & 12 & $23.9 \pm 14.5 \mathrm{bA}$ \\
\hline Phorid larvae & 7 & $8.7 \pm 8.1 \mathrm{aA}$ & 9 & $17.7 \pm 7.3 \mathrm{aB}$ & 7 & $15.0 \pm 6.4 \mathrm{bA}$ & 9 & $19.4 \pm 4.4 \mathrm{bA}$ \\
\hline
\end{tabular}

Means within a column followed by different lower-case letters, and means within a row followed by different upper-case letters, are significantly different $(P<0.05)$

Table 2 Survival and mortality tables of Parasitus bituberosus on different food sources

\begin{tabular}{|c|c|c|c|c|c|}
\hline $\begin{array}{l}\text { Predator } \\
\text { stage }\end{array}$ & Prey type & $\begin{array}{l}\text { No. alive at } \\
\text { start of stage } \\
\text { interval }\left(n_{x}\right)\end{array}$ & $\begin{array}{l}\text { Proportion } \\
\text { survived at } \\
\text { start of stage } \\
\text { interval }\left(l_{x}\right)\end{array}$ & $\begin{array}{l}\text { No. died within } \\
\text { stage interval } \\
\mathrm{X} \text { to } \mathrm{X}+1 \\
\left(d_{x}\right)\end{array}$ & $\begin{array}{l}\text { Finite rate } \\
\text { of mortality } \\
\left(q_{x}\right)\end{array}$ \\
\hline \multirow[t]{4}{*}{ Eggs } & Rhabditid nematodes & 50 & $1.0 \mathrm{a}$ & 0 & 0.0 \\
\hline & Pygmephorid mites & 49 & $1.0 \mathrm{a}$ & 16 & 0.33 \\
\hline & Sciarid larvae & 50 & $1.0 \mathrm{a}$ & 9 & 0.18 \\
\hline & Phorid larvae & 49 & $1.0 \mathrm{a}$ & 5 & 0.10 \\
\hline \multirow[t]{4}{*}{ Larvae } & Rhabditid nematodes & 50 & $1.0 \mathrm{a}$ & 7 & 0.14 \\
\hline & Pygmephorid mites & 33 & $0.67 \mathrm{c}$ & 7 & 0.21 \\
\hline & Sciarid larvae & 41 & $0.82 \mathrm{bc}$ & 9 & 0.22 \\
\hline & Phorid larvae & 44 & $0.90 \mathrm{~b}$ & 7 & 0.16 \\
\hline \multirow[t]{4}{*}{ Protonymphs } & Rhabditid nematodes & 43 & $0.86 a$ & 6 & 0.14 \\
\hline & Pygmephorid mites & 26 & $0.53 b$ & 2 & 0.08 \\
\hline & Sciarid larvae & 32 & $0.64 \mathrm{ab}$ & 3 & 0.09 \\
\hline & Phorid larvae & 37 & $0.76 \mathrm{ab}$ & 9 & 0.24 \\
\hline \multirow[t]{4}{*}{ Deutonymphs } & Rhabditid nematodes & 37 & $0.74 \mathrm{a}$ & 6 & 0.16 \\
\hline & Pygmephorid mites & 24 & $0.49 \mathrm{a}$ & 6 & 0.25 \\
\hline & Sciarid larvae & 29 & $0.58 \mathrm{a}$ & 5 & 0.17 \\
\hline & Phorid larvae & 28 & $0.57 \mathrm{a}$ & 28 & 1.0 \\
\hline \multirow[t]{4}{*}{ Adults } & Rhabditid nematodes & 31 & $0.62 \mathrm{a}$ & 31 & 1.0 \\
\hline & Pygmephorid mites & 18 & $0.37 \mathrm{~b}$ & 18 & 1.0 \\
\hline & Sciarid larvae & 24 & $0.48 \mathrm{ab}$ & 24 & 1.0 \\
\hline & Phorid larvae & 0 & 0.0 & 0 & 0.0 \\
\hline
\end{tabular}

Means within a predator stage followed by different letters are significantly different according to multiple comparisons for the corresponding model (see text) $(P<0.05)$

fecundity $(P<0.001)$. Because of an incomplete life cycle of $P$. bituberosus on phorid larvae, this diet was not included in the statistical analyses. The duration of oviposition period, like longevity, was independent of the type of food (Table 4). Because most females-about $95 \%$-laid eggs on the day of pairing and copulation with a male, and $85 \%$ of them died on the day of laying the last eggs or the next day, the analyses did not include the data on duration of pre- and postoviposition period. 


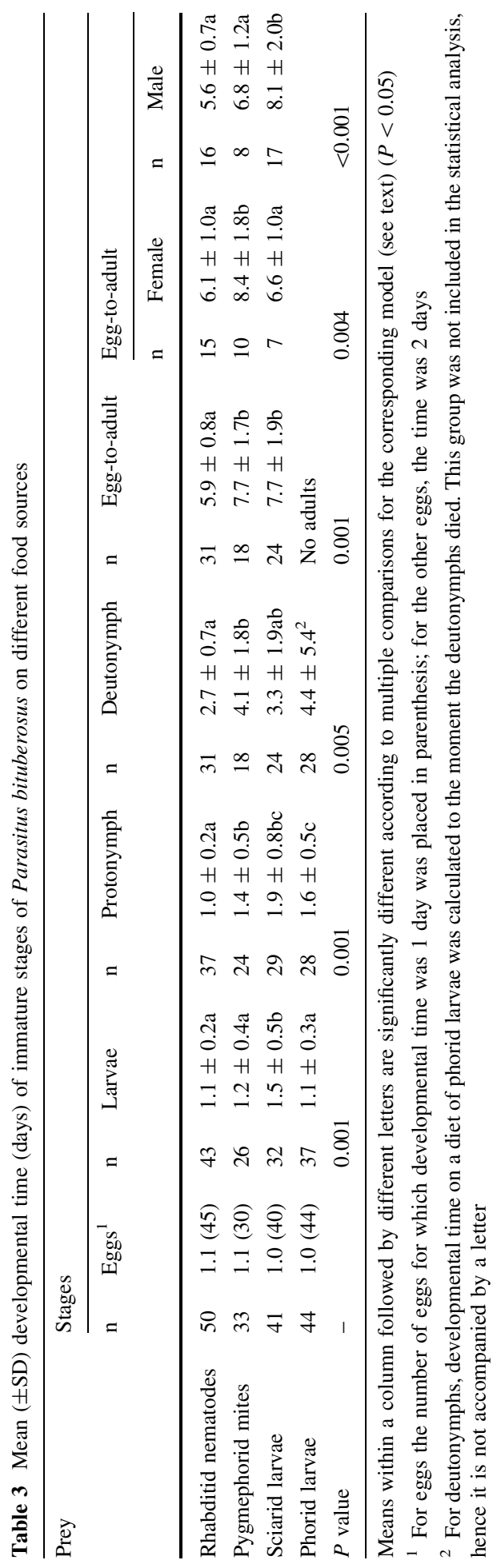


Life-history data obtained from daily observations were used to construct life tables (Table 5). The intrinsic rate of natural increase $\left(r_{m}\right)$, fine rate of increase $(\lambda)$ and net reproductive rate $\left(R_{0}\right)$ were highest for the nematode diet. Sciarid larvae turned out to be a worse diet than nematodes and better than pygmephorid mites. Differences in the mean values of those three parameters were significant for all diets, except for phorid larvae, a diet on which no adult predators were obtained. Mean generation time $(T)$ was the shortest for $P$. bituberosus fed on nematodes, no differences were detected among the other diets.

Distribution of the age-specific survival rate $\left(l_{x}\right)$ of female is presented in Fig. 1 . These findings confirmed that in all of the prey species examined, the survival curve is type I, as parameter $c$ describing the shape of the Weibull curve is higher than 1 (Pinder et al. 1978), but they were different in the scale parameter $(b)$. For females reared on rhabditid nematodes and sciarid larvae, the survival curves had very similar shapes. The survival curve of females reared on pygmephorid larvae fell more sharply than the two other curves after day 4 of female life.

The age-specific fecundity curves $\left(m_{x}\right)$ for the diets differed in shape. For nematodes and pygmephorid mites the data fitted a linear function, representing a constant decrease of fecundity rate. Data for sciarid larvae diet fitted a third-order polynominal function; the curve was almost flat (i.e., parameter values were more or less constant) from the second to the eighth day in terms of female age since maturity (Fig. 2).

Table 4 Mean $( \pm S D$ ) female longevity (days), duration of the oviposition period (days), total fecundity (eggs/female), daily fecundity (eggs/female/oviposition day) and sex ratio (female/female + male) of Parasitus bituberosus on different food sources

\begin{tabular}{lllllll}
\hline Prey & $\mathrm{n}$ & $\begin{array}{l}\text { Longevity } \\
\text { of females }\end{array}$ & $\begin{array}{l}\text { Oviposition } \\
\text { period }\end{array}$ & $\begin{array}{l}\text { Total } \\
\text { fecundity }\end{array}$ & $\begin{array}{l}\text { Daily } \\
\text { fecundity }\end{array}$ & $\begin{array}{l}\text { Sex } \\
\text { ratio }\end{array}$ \\
\hline Rhabditid nematodes & 30 & $6.5 \pm 2.5 \mathrm{a}$ & $5.4 \pm 2.6 \mathrm{a}$ & $59.5 \pm 33.1 \mathrm{a}$ & $10.4 \pm 4.2 \mathrm{a}$ & 0.48 \\
Pygmephorid mites & 28 & $5.4 \pm 1.5 \mathrm{a}$ & $4.2 \pm 1.9 \mathrm{a}$ & $18.1 \pm 11.6 \mathrm{~b}$ & $4.2 \pm 2.1 \mathrm{~b}$ & 0.58 \\
Sciarid larvae & 21 & $5.8 \pm 3.0 \mathrm{a}$ & $5.4 \pm 2.9 \mathrm{a}$ & $51.3 \pm 34.2 \mathrm{a}$ & $8.9 \pm 3.4 \mathrm{a}$ & 0.50 \\
Phorid larvae & No adults & & & &
\end{tabular}

No adults developed on Megaselia halterata diet, so this group was not considered in statistical analyses

Means within a column followed by different letters are significantly different according to multiple comparisons for the corresponding model (see text) $(P<0.05)$

Table 5 Mean $( \pm \mathrm{SE})$ life table parameters of Parasitus bituberosus on different food sources and multiple comparisons obtained by the jackknife method

\begin{tabular}{llrlll}
\hline Prey & $\mathrm{n}$ & \multicolumn{1}{c}{$R_{0}$} & \multicolumn{1}{l}{$T$} & \multicolumn{1}{l}{$r_{m}$} & $\lambda$ \\
\hline Rhabditid nematodes & 30 & $17.7 \pm 1.80 \mathrm{c}$ & $8.5 \pm 0.27 \mathrm{a}$ & $0.34 \pm 0.01 \mathrm{c}$ & $1.40 \pm 0.02 \mathrm{c}$ \\
Pygmephorid mites & 28 & $3.9 \pm 0.47 \mathrm{a}$ & $9.9 \pm 0.21 \mathrm{~b}$ & $0.14 \pm 0.01 \mathrm{a}$ & $1.15 \pm 0.01 \mathrm{a}$ \\
Sciarid larvae & 21 & $12.3 \pm 1.79 \mathrm{~b}$ & $9.8 \pm 0.35 \mathrm{~b}$ & $0.25 \pm 0.01 \mathrm{~b}$ & $1.29 \pm 0.01 \mathrm{~b}$ \\
Phorid larvae & no adults & & & & \\
\hline
\end{tabular}

Means within a column followed by different letters are significantly different, according to multiple comparisons, computed by the jackknife method $(P<0.05)$

$R_{O}$ net reproductive rate, $T$ mean generation time, $r_{m}$ intrinsic rate of population increase, $\lambda$ finite rate of population increase per female per day 


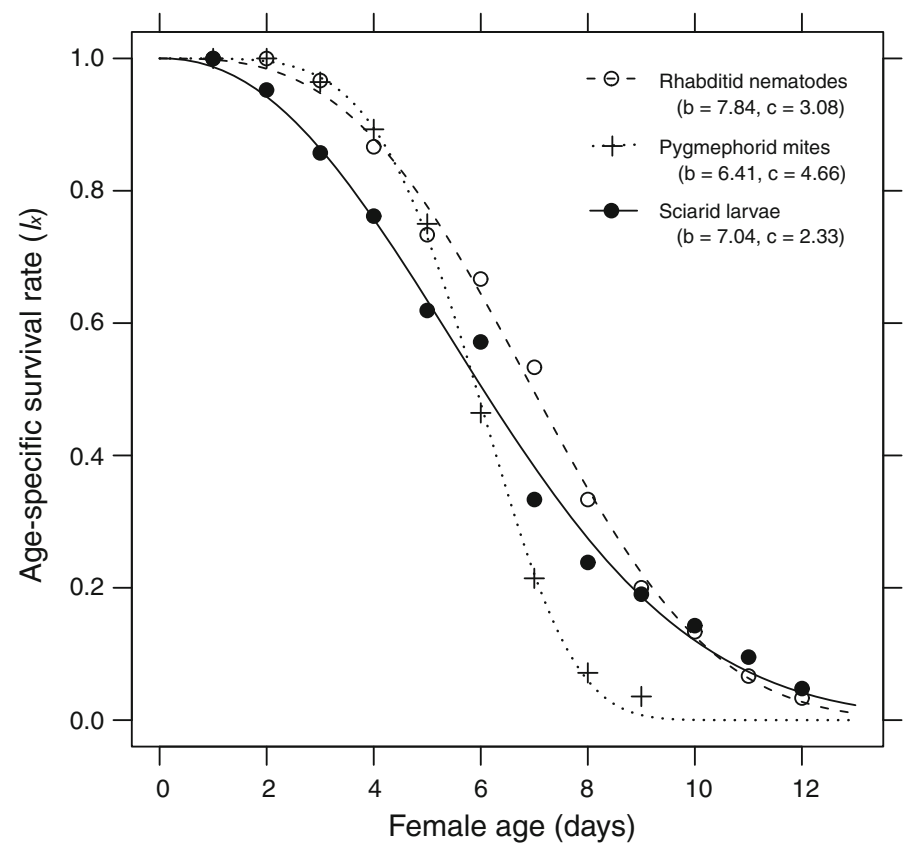

Fig. 1 Age-specific survival $\left(l_{x}\right)$ of Parasitus bituberosus females on three diets. Lines represent fitted Weibull functions with $b$ as scale and $c$ as shape parameters

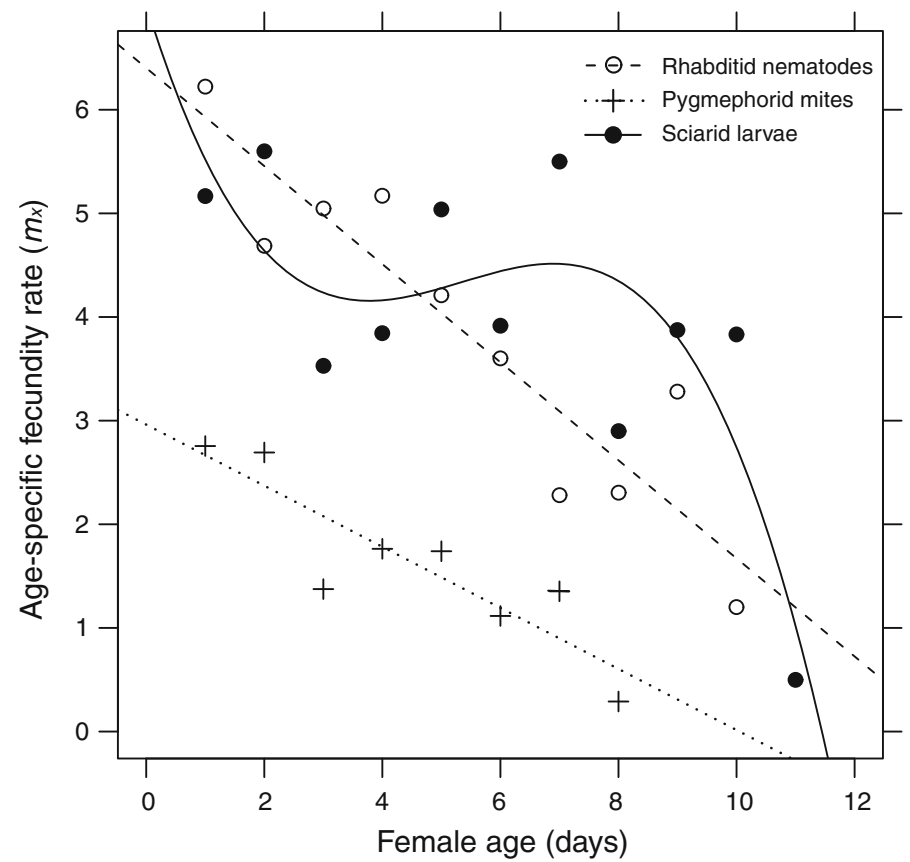

Fig. 2 Age-specific fecundity of Parasitus bituberosus females on different food diets. Lines represent fitted relationship of $m_{x}$ with female age 


\section{Discussion}

Prey acceptance tests of P. bituberosus have been conducted by Al-Amidi and Downes (1990). As a prey the authors used organisms commonly available in mushroom composts, such as larvae of cecid fly $(H$. pygmea), larvae and eggs of sciarid fly (L. ingenua), saprophagous mites (H. feroniarum), mycophagous mites (Pygmephorus sp. [=Pediculaster]) and springtails. Deutonymphs of the predator most frequently chose cecid and sciarid larvae as food, and seldomly sciarid eggs and springtails. In our studies the testing method and types of food were slightly different: the most common and economically important organisms in Polish mushroom houses were used, so that it was possible to evaluate which of them might be the main diet of this predator. Neither deutonymphs nor females showed preferences towards prey, which indicates that $P$. bituberosus in mushroom houses can feed on all invertebrates that inhabit growth medium used for mushroom cultivation. Very interesting are differences in choosing pygmephorid mites in our results and those obtained by Al-Amidi and Downes (1990). Al-Amidi and Downes did not observe deutonymphs feeding on $\mathrm{H}$. feroniarum and Pediculaster sp., whereas our data demonstrated that starving deutonymphs chose pygmephorid mites as frequently as the other kinds of food. These differences can be a result of using normal and phoretic females of $P$. mesembrinae in the present study. We suspect that phoretic females, which are highly sclerotized, could be less accepted than normal ones. Unfortunately, Al-Amidi and Downes (1990) did not mention the stage of pygmephorid mites offered as a prey. An alternative explanation of these differences can be genetic differences in prey preferences among the studied populations of $P$. bituberosus. Such a phenomenon was observed in local populations of Hypoaspis aculifer (Canestrini) (Lesna and Sabelis 1999, 2002).

To find the prey deutonymphs needed twice as much time as females. According to our observations, deutonymphs in the phoretic stage are more active than females, and any perturbation of rearing boxes elicits activity of deutonymphs, which probably promotes searching for phoretic hosts and probably results from a motivational drive to reproduce (AlAmidi and Downes 1990). Deutonymphs of this mite species experience periodic starvation, thereby prolonging the time of searching prey. Worth noticing is the significant difference in time of feeding on nematodes and dipteran larvae, as observed for both developmental stages of the predator. This was probably due to the difference in size of the prey: much smaller and more numerous than dipterans, nematodes were caught and eaten faster. The opposite situation was observed for sciarid and phorid larvae, which are much bigger than P. bituberosus - for this reason the predator needed much more time to attack and kill the prey.

Choice tests were also conducted by Rudzińska-Sajdak (1998) for A. semiscissus, which occurs in mushroom houses. The mites preferred nematodes and eggs and larvae of the sciarid Lycoriella castanescens (Lengersdorf), but did not show much interest in larvae of the cecidomyiid H. pygmaea or in acaroid Tyrophagus putrescentiae (Schrank) mites. Interestingly, Rudzińska-Sajdak's (1998) choice tests showed a positive influence of the previous diet on prey choice. This phenomenon was not studied in the present study, but the fact that individuals used in the choice tests came from the cultivation on nematodes and yet did not choose this food most frequently may suggest that the association found by Rudzińska-Sajdak did not apply to our study. This, together with lack of differences in the choice of food, suggests that $P$. bituberosus is polyphagous, which agrees with Binns' (1973a) observations, who found that in mushroom compost it accepts a wide range of prey, including eelworms, insect larvae and mites. The author claimed his observations dealt with Parasitus fimetorum (Berlese), but this identification was likely incorrect. Al- 
Amidi and Downes (1990) suggest that Binns' identifications were probably based on Costa (1961). According to Hyatt (1988), Karg (1972) described P. bituberosus from larvae, protonymphs, deutonymphs, males and females collected from agricultural soils at Cottbus (East Germany) and Cape Town (South Africa). Karg also stated that $P$. fimetorum sensu Costa (1961) from Israel was not Berlese's fimetorum, but was conspecific with bituberosus.

Despite the lack of preferences of $P$. bituberosus towards the food sources studied, it was noted that the mean developmental time of immature stages and fecundity of females were determined by differences in diet. Taking into account mean developmental time of immature stages - from egg to adult — nematodes turned out to be the best prey for these predator stages, whereas phorid larvae should be considered as the worst food. Immatures originating from eggs laid by females from a stock colony, feeding upon larvae of these flies, reached the deutonymph stage; however, after being moved to a new environment with the very same food, they did not reach maturity. Such late inhibition of immature development of $P$. bituberosus suggests that the negative influence of phorid larvae diet is not connected with quality of the food, but rather with the behaviour of either prey or predator. This phenomenon needs scrutiny in future experiments. One hypothesis is that the physiological step to maturity poses special nutritional requirements that may not be fulfilled by phorid larvae. Alternatively, Yasui (1997) hypothesized that immature predators need the presence of the other sex before they develop to maturity. However, this hypothesis was falsified by our observations that maturity was reached in absence of the other sex, yet there may still be an interaction with nutritional requirements (the first hypothesis).

The life tables show an effect of diets. With respect to intrinsic rate of population increase $\left(r_{m}\right)$ and mean generation time $(T)$, nematodes were the best food for P. bituberosus. The second best food was sciarid larvae, whereas the worst diet involved phorid larvae, especially because the predators did not complete their development. Taking into account the size of the various types of food tested, one can suppose that nematodes, being the smallest, were the easiest to capture for the P. bituberosus immature stages, as can be inferred from the length of egg-to-adult developmental time (Table 3). Because of the big size of sciarid larvae as compared to nematodes, immature individuals needed more time and energy to kill the prey (Sabelis 1985, 1992). Such a conclusion may seem in conflict with the results on length of developmental time for immature stages of $P$. bituberosus fed on pygmephorid mites, because the prey is smaller than sciarid larvae. In this case, the time was similar to that for P. bituberosus fed on sciarids. Nonetheless, it should be taken into account that pygmephorid females and the youngest instars of sciarids have similar body size. Body length of females of P. mesembrinae ranges from 0.17 to $0.25 \mathrm{~mm}$ (Hussey et al. 1969; Camerik et al. 2006), whereas body length of the first larval instar of sciarids ranges from 0.36 to $1.40 \mathrm{~mm}$ (Lewandowski et al. 2004). In addition, life table parameters (Table 5) and fecundity (Table 4) suggest that, phorid larvae put aside, $P$. mesembrinae was the worst type of food also for females of P. bituberosus, even though the size of prey was not so important for adults of the predator. We observed that females were able to kill the third instar of phorid larvae or even the fourth instar of sciarid larvae, whose body length can reach even 3.8 and $7.9 \mathrm{~mm}$, respectively (Lewandowski et al. 2004, 2012). The $r_{m}$ values for females fed on this prey were more than twice smaller than for those fed on nematodes and sciarid larvae, and fecundity was almost three times smaller. Therefore, one could suppose that pygmephorid mites can be eaten by all developmental stages of the predator, but the nutritional value of this food is likely smaller than that of the two other types of food. Reasons for this phenomenon are difficult to establish, but supposedly it 
results from composition of nutrients or defensive (unpalatable) chemical compounds of the prey (Sabelis 1985, 1992).

Life table parameters of $P$. bituberosus, and especially intrinsic rate of population increase $\left(r_{m}\right)$, enable one to compare its bionomy with that of other species occurring in mushroom houses. Slightly smaller values of $r_{m}$ (0.32 females/female/day) together with longer mean generation time $(T)$ was observed for species Proctolaelaps deleoni Nawar, Childers and Abou-Setta, belonging to the family Ascidae, reared on nematodes at the same temperature (Nawar 1992). Smaller values of $r_{m}(0.23)$ were also recorded by Rudzińska (1998) for A. semiscissus, which belongs to the same family as $P$. deleoni, fed upon eggs of sciarids. In this case, the parameter value could depend on the type of food and temperature, which was lower $\left(20^{\circ} \mathrm{C}\right)$ than in the present study. Sciarid larvae were used as food by Enkegaard et al. (1997) to study bionomy of $H$. miles in $20^{\circ} \mathrm{C}$. Intrinsic rate of population increase observed by these authors was surprisingly low (0.07). The high value of this parameter obtained during the present studies suggest that $P$. bituberosus is better adapted to the environment of mushroom houses than A. semiscissus and H. miles, which in turn might suggest $P$. bituberosus as a potential agent for mushroom pest control.

A comparison of life table parameters between $P$. bituberosus and other species of the Parasitidae family would be very interesting, but unfortunately such information is very scarce. The only available data are for $R$. consanguineus (Szlendak and Lewandowski 2009). This publication does not contain $r_{m}$ values; the authors report fecundity, longevity and duration of oviposition period for the species reared on phorid and sciarid larvae. What was interesting in their experiment was that $R$. consanguineus completed its development on both these diets. Female longevity of $R$. consanguineus reared on sciarid larvae (mean of 6.9) was slightly longer than that for P. bituberosus (mean of 5.8) reared on the same diet, whereas duration of oviposition period was similar for both species (mean of 5.0 and 5.4 days, respectively). Worth noticing is that $R$. consanguineus was reared at a lower temperature $\left(21^{\circ} \mathrm{C}\right)$, which can be a reason for this difference. However, fecundity of $R$. consanguineus (17.8 eggs/female) was noticeably smaller as compared to that of P. bituberosus (51.3). Fecundity of $R$. consanguineus was similar to that obtained for P. bituberosus reared on pygmephorid mites, which were the worst food among those which allowed for complete development of the mites. The almost 3 times higher fecundity of those two prey species seems not to be affected by the differences in temperature during the experiments. Hence, inter-species differences among these predators are likely to be the case.

Unpublished data (Szafranek and Lewandowski) showed that P. bituberosus is common in mushroom houses in Poland: it was recorded in half of them. From the data obtained by Al-Amidi and Downes (1990) and Al-Amidi et al. (1991) it follows that the mites can feed on all small invertebrates that infest mushroom houses, thereby limiting their population density. Their potential for reducing sciarid larvae and rhabditid nematodes was proven by the high values of life table parameters. Intrinsic rate of natural increase $\left(r_{m}\right)$ of $P$. bituberosus fed on these prey species was higher than that for the other predatory mites studied under similar conditions (Nawar 1992; Enkegaard et al. 1997; Rudzińska 1998). A comparison of the parameters, especially $r_{m}$, between the prey species and the predator would be very useful to confirm the idea of using $P$. bituberosus as an agent for biological control of mushroom pest. Roy et al. (2003) stated that $r_{m}$ values can be useful in biological control practice as a means of selecting promising biocontrol candidates on the basis of their reproductive potential. According to Janssen and Sabelis (1992), Sabelis (1992) and Sabelis et al. (2002), theoretically a predator that has a population growth rate equal to or greater than its prey should effectively regulate its population (given a sufficiently high predator-prey ratio at introduction). Unfortunately, to the best of our knowledge life table 
parameters for L. ingenua are not available in the literature, although it is the main mushroom pest. Such information is available for the pygmephorid mite P. mesembrinae. Hernández-Abarca et al. (2005) presented values of $r_{m}$ obtained for the mites reared in $25{ }^{\circ} \mathrm{C}$ on $T$. harzianum, which were slightly higher $(0.17)$ than those calculated for $P$. bituberosus (0.14) reared on the P. mesembrinae served as a prey (see Table 5). This suggests that the predator may not be an effective agent for biological control of pygmephorid mites. Worth noticing is that the authors mentioned T. hartzianum as a nonsuitable food source for the pest. Probably, P. mesembrinae feeding on other fungi, such as Chrysonilia sitophila, Cladobotryum dendroides or Mycogone perniciosa, can achieve higher values of these parameters, than P. bituberosus. Life table parameters for rhabditid nematodes were presented by Venette and Ferris (1997). These authors studied the influence of temperature on the finite rate of increase of a few species of bacterial-feeding nematodes, including Rhabditis cucumeris: at $25^{\circ} \mathrm{C}$ it was ca. 1.00 which was lower than the 1.40 we found for P. bituberosus. At $20{ }^{\circ} \mathrm{C}$, however, it increased more than twice (ca. 2.3 ), suggesting that in this lower temperature the efficiency of predatory mites can be noticeably lower.

It is still premature to rate $P$. bituberosus as an effective natural enemy of rhabditid nematodes and pygmephorid mites, because life table parameters do not seem to be totally convincing and because mushroom mycelium has a strong negative effect on populations of the pest (Gurney and Hussey 1967; Dmowska et al. 1997). Mushroom mycelium colonizing compost used for mushroom production absorbs much of free water and creates a bacteriostatic zone, which can inhibit development of these small animals (Hesling 1966). However, data presented by Al-Amidi and Downes (1990) and Al-Amidi et al. (1991) show $P$. bituberosus is effective against sciarid and cecidomyiid flies, and its introduction to mushroom beds increases mushroom yield and limits contamination of mushrooms by cecidomyiid larvae. Based on these results, Al-Amidi et al. (1991) recommended the species for use in integrated pest management. The results of the present research seem to confirm the validity of this hypothesis, especially in the case of sciarid fly control. Furthermore, the ability of $P$. bituberosus to prey on pygmephorid mites and rhabditid nematodes indicates that the predator can inhibit growth of this pest population when the growth medium is well colonized by mushroom mycelium.

Acknowledgments We would like to thank Prof. Stanisław Ignatowicz from Department of Applied Entomology, Warsaw University of Life Sciences-SGGW for help in designing, conducting and interpreting the experiments, Prof. Danuta Kropczyńska and Dr. Ewa Puchalska from the same department for comments on former versions of this manuscript, and one of the anonymous reviewers for very deep and helpful thoughts on the manuscript. This study was supported financially by Polish Ministry of Science and Higher Education in years 2005-2008 (Grant no. 2P06R09928). Part of this work was conducted while Marcin Kozak was in the Department of Experimental Design and Bioinformatics, Warsaw University of Life Sciences-SGGW.

Open Access This article is distributed under the terms of the Creative Commons Attribution License which permits any use, distribution, and reproduction in any medium, provided the original author(s) and the source are credited.

\section{References}

Agresti A (2002) Categorical data analysis, 2nd edn. Wiley, New York

Al-Amidi AHK, Downes MJ (1990) Parasitus bituberosus (Acari: Parasitidae), a possible agent for biological control of Heteropeza pygmaea (Diptera: Cecidomyiidae) in mushroom compost. Exp Appl Acarol 8:13-25 
Al-Amidi AHK, Dunne R, Downes MJ (1991) Parasitus bituberosus (Acari: Parasitidae): an agent for control of Lycoriella solani (Diptera: Sciaridae) in mushroom crops. Exp Appl Acarol 11:159-166

Binns ES (1972) Arctoseius cetratus (Sellnick) (Acarina: Ascidae) phoretic on mushroom sciarid flies. Acarologia 14:350-356

Binns ES (1973a) Predatory mites—neglected allies? Mushroom J 12:540-544

Binns ES (1973b) Digamasellus fallax Leitner (Mesostigmata: Digamasellidae) phoretic on mushroom sciarid flies. Acarologia 15:10-17

Binns ES (1974) Notes on the biology of Arctoseius cetratus (Sellnick) (Mesostigmata: Ascidae). Acarologia 16:577-582

Birch LC (1948) The intrinsic rate of natural increase of an insect population. J Anim Ecol 17:15-26

Camerik AM, de Lillo E, Lalkhan C (2006) The neotype of Pediculaster mesembrinae (Canestrini, 1881) (Acari: Siteroptidae) and the description of all life stages. Int J Acarol 32:45-67

Chambers RJ, Wright EM, Lind RJ (1993) Biological control of glasshouse sciarid flies (Bradysia spp.) with the predatory mite, Hypoaspis miles, on Cyclamen and Poinsettia. Biocontrol Sci Tech 3:285-293

Clift AD, Terras MA (1995) Mites as indicator of compost conditioning. In: Eliot TJ (ed) Science and cultivation of edible fungi. AA Balkema, Rotterdam, pp 507-513

Costa M (1961) Mites recovered from the nests of the levant vole (Microtus guenthreri) in Israel. Ann Mag Nat Hist 13:257-282

Dmoch J (1995) Arctoseius semiscissus (Berlese, 1892) phoretic on mushroom sciarid flies in Poland-a possible agent for biological control of sciarids in mushroom houses. In: Elliott TJ (ed) Science and cultivation of edible fungi. AA Balkema, Rotterdam, pp 533-537

Dmowska E, Dmoch J, Ilieva K (1997) Early interaction of the bacterivorous nematodes Rhabditis cucumeris and the edible fungus Agaricus bisporus in relation to time and quality of nematode inoculation. Int J Mushroom Sci 2:15-23

Enkegaard A, Sardar MA, Brødsgaard HF (1997) The predatory mite Hypoaspis miles: biological and demographic characteristics on two prey species, the mushroom sciarid fly, Lycoriella solani, and the mould mite, Tyrophagus putrescentiae. Entomol Exp Appl 82:135-146

Gill RS, Sandhu GS, Dhooria MS (1988) Studies on the pest and predatory status of mite Parasitus consanguineus Oudemans \& Voigts (Parasitidae: Mesostigmata: Acari) occurring in Punjab. Indian J Mushrooms 14:32-36

Gillespie RD, Quiring DMJ (1990) Biological control of fungus gnat, Bradysia spp. (Diptera: Sciaridae), and western flower thrips, Frankliniella occidentalis (Pergande) (Thysanoptera: Thripidae), in greenhouses using a soil-dwelling predatory mite, Geolaelaps sp. nr. aculeifer (Canestrini) (Acari: Laelapidae). Can Ent 122:975-983

Gurney B, Hussey NW (1967) Pygmephorus species (Acarina: Pyemotidae) associated with cultivated mushrooms. Acarologia 9:353-358

Hernández-Abarca JT, Otero-Colina G, Vera-Graziano J, Luis J, Alvarado-Rosales D, Aranda-Escobar E (2005) Life tables and thermal constants of Pediculaster mesembrinae (Acari: Siteroptidae) fed on the fungus, Trichoderma harzianum Rifai. Int J Acarol 31:165-170

Hesling JJ (1966) The effects of some microphagous saprobic nematodes on mushroom culture. Ann Appl Biol 58:477-486

Hothorn T, Bretz F, Westfall P (2008) Simultaneous inference in general parametric models. Biometrical J 50:346-363

Hussey NW, Read WH, Heslling J (1969) The biology and control of glasshouse and mushroom pests. Edward Arnold, London, UK

Hyatt KH (1980) Mites of the subfamily Parasitinae (Mesostigmata: Parasitidae) in the British Isles. Bull Br Mus Nat Hist Zool 38:237-378

Hyatt KH (1988) Two species of Parasitus (Acari: Mesostigmata) new to the British Isles. It Nat J 22:393-403

Janssen A, Sabelis MW (1992) Phytoseiid life-histories, local predator-prey dynamics, and strategies for control of tetranychid mites. Exp Appl Acarol 14:233-250

Jess S, Bingham JFW (2004) Biological control of sciarid and phorid pests of mushroom with predatory mites from the genus Hypoaspis (Acari: Hypoaspidae) and the entomopathogenic nematode Steinernema feltiae. Bull Entomol Res 94:159-167

Karg W (1972) Zur Kenntnis der Gattung Parasitus Latreille, 1795 (Acarina, Parasitiformes) aus Komposterden und Gurkenkulturen. Dtsch Entomol Z 19:55-63

Kozak M (2009) Analyzing one-way experiments: a piece of cake or a pain in the neck? Sci Agric 66:556-562

Kropczyńska-Linkiewicz D (1984) Roztocze (Acari). In: Dmoch J (ed) Fauna pieczarkarni w Polsce. Wydawnictwo SGGW, Warszawa, pp 32-53 
Lesna I, Sabelis MW (1999) Diet-dependent female choice for males with 'good genes'. Nature 401:581-584

Lesna I, Sabelis MW (2002) Genetic polymorphism in prey preference at a small spatial scale: a case study of soil predatory mites (Hypoaspis aculeifer) and two species of astigmatic mites as prey. In: Bernini F, Nannelli R, Nuzzaci G, de Lillo E (eds) Acarid phylogeny and evolution: adaptation in mites and ticks-proceedings of the IV symposium of the European Association of Acarologists. Kluwer, Dordrecht, pp 49-64

Lewandowski M, Sznyk A, Bednarek A (2004) Biology and morphology of Lycoriella ingenua (Diptera: Sciaridae). Biological Lett 41:41-50

Lewandowski M, Kozak M, Sznyk-Basałyga A (2012) Biology and morphometry of Megaselia halterata, an important insect pest of mushrooms. Bull Insectol 65:1-8

Maia AHN, Luiz AJB, Campanhola C (2000) Statistical inference on associated fertility life table parameters using Jackknife technique: computational aspects. J Econ Entomol 93:511-518

Nawar MS (1992) Life tables of Proctolaelaps deloni Nawar, Childers and Abou-Setta (Gamasida: Ascidae) at different temperatures. Exp Appl Acarol 13:281-285

Pinder JE, Wiener JG, Smith MH (1978) The Weibull distribution: a new method of summarizing survivorship data. Ecology 59:175-179

Pinheiro JC, Bates DM (2000) Mixed-effects models in S and S-PLUS. Springer, New York

R Development Core Team (2009) R: A language and environment for statistical computing. R Foundation for Statistical Computing, Vienna, Austria

Rinker DL, Snetsinger RJ (1984) Damage threshold to a commercial mushroom by a mushroom-infesting phorid (Diptera: Phoridae). J Econ Entomol 77:449-453

Roy M, Brodeur J, Cloutier C (2003) Effect of temperature on intrinsic rates of natural increase $\left(r_{m}\right)$ of a coccinellid and its spider mite prey. Biocontrol 48:57-72

Rudzińska M (1998) Life history of the phoretic predatory mite Arctoseius semiscissus (Acari: Ascidae) on a diet of sciarid fly eggs. Exp Appl Acarol 22:643-648

Rudzińska-Sajdak M (1998) Ocena znaczenia Arctoseius semiscissus (Berlese, 1892) (Acarina: Ascidae) dla potrzeb biologicznego zwalczania ziemiórek. Dissertation, Warsaw University of life SciencesSGGW

Sabelis MW (1985) Predation on spider mites. In: Helle W, Sabelis MW (eds) Spider mites, their biology, natural enemies and control, vol 1B. Elsevier, Amsterdam, pp 103-129

Sabelis MW (1992) Predatory arthropods. In: Crawley MJ (ed) Natural enemies. The population biology of predators, parasites and disease. Blackwell, Oxford, pp 225-264

Sabelis MW, van Baalen M, Pels B, Egas M, Janssen A (2002) Evolution of exploitation and defence in plant-herbivore-predator interactions. In: Dieckmann U, Metz JAJ, Sabelis MW, Sigmund K (eds) The Adaptive dynamics of infectious diseases: in pursuit of virulence management. Cambridge University Press, Cambridge, pp 297-321

Szlendak E, Lewandowski M (2000) Parasitus consanguineus (Mesostigmata: Parasitidae) newly reported species of predatory mite occurring in Polish mushroom houses. In: Ignatowicz S (ed) Materialy XXVI Sympozjum Akarologicznego „Akarologia polska u progu nowego tysiąclecia”. Wydawnictwo SGGW, Warszawa, pp 143-148

Szlendak E, Lewandowski M (2009) Development and reproductive capacity of the predatory mite Parasitus consanguineus (Acari: Parasitidae) reared on the larval stages of Megaselia halterata and Lycoriella ingenua. Exp App Acarol 47:285-292

Trivedi TP (1988) Occurrence of mite in the beds of cultivated mushroom. Curr Res Univ Agric Sci Bangalore 17:125

Venette RC, Ferris H (1997) Thermal constrains to population growth of bacterial-feeding nematodes. Soil Biol Biochem 29:63-74

Webster R (2007) Analysis of variance, inference, multiple comparisons and sampling effects in soil research. Eur J Soil Sci 58:74-82

White PF (1981) The spread of the mushroom diseases Verticillium fungicola by Megaselia halterata. Prot Ecol 3:17-24

White PF (1986) The effect of sciarid larvae (Lycoriella auripila) on the yield of the cultivated mushroom (Agaricus bisporus). Ann Appl Biol 109:11-17

Wright EM, Chambers RJ (1994) The biology of the predatory mite Hypoaspis miles (Acari: Laelapidae), a potential biocontrol agent of Bradysia paupera (Dipt.: Sciaridae). Entomophaga 39:225-235

Yasui Y (1997) Sperm competition and the significance of female multiple mating in the predatory mite Parasitus fimetorum. Exp App Acarol 21:651-664 